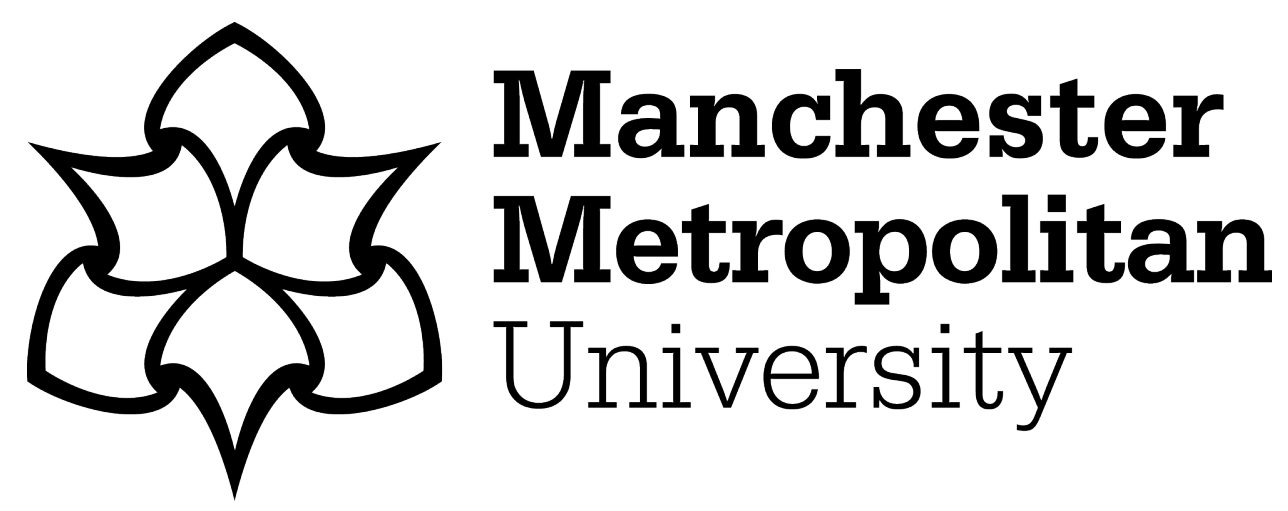

Ivinson, Gabrielle ORCID logoORCID: https://orcid.org/0000-0002-55529601 and Bright, Nigel (2019) Washing lines, whinberries and reworking 'waste ground': Women's affective practices and a haunting within the haunting of the UK coalfields. Journal of Working-Class Studies, 4 (2). pp. 125139. ISSN 2475-4765

Downloaded from: https://e-space.mmu.ac.uk/624678/

Version: Published Version

Publisher: Journal of Working-Class Studies Association

Please cite the published version 


\title{
Washing lines, whinberries and reworking 'waste ground': Women's affective practices and a haunting within the haunting of the UK coalfields
}

\author{
Geoff Bright and Gabrielle Ivinson, Education and Social Research Institute, \\ Manchester Metropolitan University, UK
}

\begin{abstract}
This article reflects on a series of 'Ghost lab' events (Bright 2019) with local people where creative memory work - stimulated by songs, films, and readings from a pack of what we have called a 'Community Tarot' cards (our main focus here) - was used to register aspects of what, following Gordon (2008), we are calling a 'social haunting' of former coal-mining communities in the north of England and the valley communities of south Wales. The events were part of a joint 2018-19 research project called Song lines on the road - Life lines on the move! (On the Road for short) that sought to share two independent strands of longitudinal, co-produced, arts-based research in which we have developed approaches aimed at amplifying how living knowledge flows on in communities even when the shocks and intensities of lived experience defy articulation and representation. During the last decade or so both of us have worked with artists to co-produce research projects that enable young people and marginalised adults to communicate with and challenge authority by drawing on the affective power of art. Independently of each other until now, we have both been using creative/affective methodologies to understand how classed and gendered circuits of affect both reproduce and reconfigure vernacular bonds of solidarity and practices of wellbeing in multiple impoverished coalfield communities.
\end{abstract}

\section{Keywords}

Ghost labs, former coal-mining communities, north of England, south Wales, social haunting, creative memory work

\section{Introduction}

This article reflects on a series of 'Ghost Labs' that took place in former coal-mining communities in the north of England and the valleys of south Wales during 2018. In each Ghost Lab, (a community workshop design we will describe in detail below) creative memory work - stimulated by films and readings ${ }^{1}$ from a pack of what we have called 'Community Tarot' cards - was used to highlight aspects of what, following Avery Gordon (2008), we are calling a 'social haunting' of such communities. The Ghost Labs were part of a 2018-19 research project that we undertook jointly from our base in the Education and Social Research Institute at Manchester Metropolitan University in the UK. Called Song lines on the road - Life lines on the move! (On the Road for short) our project

\footnotetext{
${ }^{1}$ Using a simple three-card reading from a pack of 'Community Tarot' cards produced collaboratively with our community partners, this process facilitates a playful, creatively generative reflection on aspects of community presents/pasts/futures. Each card carries a name or image generated in project co-production.
} 
sought to bring together two different strands of longitudinal, co-produced, arts-based research in which we have each developed a distinctive approach to understanding how classed and gendered circuits of affect ${ }^{2}$ can disturb and reconfigure vernacular bonds of solidarity in deindustrialised communities.

Writing out of a life lived in the Derbyshire and South Yorkshire coalfields - as a child in a pit family, as a worker and trade union activist, and as a teacher in adult and community education Bright has developed a body of research (see, for example, Bright 2012a; 2012b; 2016; 2018), the most recent of which uses comic strip, group poetry, community broadcasting, community theatre and song to explore how the haunted entanglement of affect and imagination in working-class experience has played out in the thirty-year period of coalfield de-industrialisation). 2018 saw the completion of the last of three consecutive UK Arts and Humanities Research Council Connected Communities projects led by him that have considered various aspects of that topic. ${ }^{3}$ (See https://www.socialhaunting.com/).

Ivinson has worked in the south Wales valleys communities for over a decade (see e.g. Ivinson 2012, 2014; Ivinson \& Renold 2013a, 2013b) and has been part of large scale RCUK ${ }^{4}$ funded research projects aimed at developing research methods and methodologies. It was during this series of projects that she came to realise the limits of one-to-one interview methods, which led her to develop arts-based approaches along with Emma Renold and a range of visual, audio and film-making artists ${ }^{5}$ (See https://productivemargins.blogs.bristol.ac.uk/projects/mapping-making-mobilising/).

Bringing our experience together, we developed five new Ghost Labs in our joint project - two in the north of England and three in south Wales. Each one was established in partnership with local community activists and based around an occasion of sharing food, films from our previous work, and banter in a safe and hospitable place. It is from that work that this article - which is essentially a contribution to developing 'affective methodologies' (see Knudsen \& Stage 2016) for studying the impacts of de-industrialisation - has emerged.

As we have facilitated and participated in the On the Road Ghost Labs, we have become increasingly aware of a sharp contestation among the spectres that continue to make themselves known in UK coalfield settings. Reflecting together with our commissioned artist colleagues, Steve Pool, Valerie Walkerdine and Amelia 'Unity' Thomas ${ }^{6}$, we realise just how emphatically our joint project has registered a hidden aspect of the broader social haunting of the UK coalfields: namely, how the dominant narratives of the 1984-85 Miners' Strike remain strongly masculinised ${ }^{7}$ in haunted local

\footnotetext{
${ }^{2}$ Throughout this account we are thinking of affect as 'an impingement or extrusion of a momentary or sometimes more sustained state of relation as well as the passage... of forces or intensities... that pass body to body' (Seigworth \& Gregg 2010).

${ }^{3}$ The first of these worked on the South Yorkshire coalfield during 2015, the second was based mainly on the North Staffordshire coalfield during 2016 and the most recent, Song Lines: Creating Living Knowledge through Working with Social Haunting, ran from 2017 to 2018 and extended the inquiry on to the Durham coalfield in the North East of England. The research co-production team is extensive and can be seen in full at https://www.socialhaunting.com/ourteams. In Bright's series of AHRC Connected Communities funded projects the two most significant community partners have been the Co-operative College, and Unite the Union.

${ }^{4}$ For details of one most recent multi-phase ESRC/AHRC funded project and the Productive Margins programme, see https://productivemargins.blogs.bristol.ac.uk/projects (Reference: ES/K002716/1).

${ }^{5}$ The full team for the Productive Margins work in Wales includes: Jên Angharad (choreographer), Eve Exley, Eva Elliott, Heloise Godfrey-Talbot (film-maker), Rowan Talbot (sound artist), Gabrielle Ivinson, Seth Oliver (visual artist), Emma Renold and Gareth Thomas.

${ }^{6}$ Use the 'new work' tab at https://www.socialhaunting.com/ to see the artists' work.

${ }^{7}$ Interestingly, the dominant masculinised narrative is more like to be challenged in cultural production. The films Billy Elliot and Pride being examples.
} 
coalfield settings and are, thereby, internally haunted by the still marginalised voices of coalfield women. Those voices speak to how the work of $\mathrm{Care}^{8}$ that women undertook in holding coal mining communities together through the travails of Coal's epoch of expansion continues on into the period of de-industrialisation. As our work over the last decade or so has witnessed, women (and girls) still bear the burden of nurturing children and protecting vulnerable elders in circumstances of swingeing public service cuts, often while struggling to hold down roles as precarious wage earners or, in the case of the girls, as Further Education sector students and young carers. Additionally, women and girls also labour to protect the fragile dignity of no-longer labouring men, a form of value production that partially contests, but is nevertheless firmly bound into, the residual patriarchalism that was once so dominant in coalfield culture.

Drawing on Avery Gordon's work on social haunting; Kathleen Stewart's ethnographic approach to 'ordinary affects' (2007, 2010a, 2010b); Massumi's account of micropolitics (Massumi 2015); Guattari's writing on transversal group practice and linked ecologies of sociality (Gauttari 1989, 2015); Walkerdine and Jiminez's (2012) work on the 'matrixial' in community practices, and Beverley Skeggs' account of gendered autonomous working-class value production (Skeggs 2011), we argue that the coalfield ghosts showing up in our Labs illustrate not only the existence of a gendered haunting within a haunting - and the manifold difficulties attendant on that - but also make explicit the role of women in a hopeful gendered micropolitics that, astonishingly, remains alive and well in contemporary times, in spite of the corrosive macro-political vacuum left behind by more than thirty years of corrosive neo-liberal dominion.

\section{A social haunting}

What, then, is a social haunting and why, in particular, do we argue that it applies to the UK coalfields? A social haunting, Avery Gordon argues, is made evident in social settings when 'disturbed feelings cannot be put away' (Gordon 2008, p. xvi). It is an entangling reminder of lingering trouble relating to social violence done in the past and a notification 'that what's been concealed is very much alive and present [and] showing up without any sign of leaving [and, as such] alters the experience of being in time, the way we separate the past, the present, and the future' (Gordon 2008, p. xvi). Furthermore, social ghosts, while strongly felt are, however, not easily known. Indeed, a social haunting is 'often barely visible or highly symbolized' residing at the very 'cusp of semantic availability’ (Gordon 2008, p. 50, citing Williams 1977).

It should be noted that other work has, to be fair, probed similar territory in the overlap between memory studies' focus on collective social memory (Fentress \& Wickham 1992; Olick, VinitskySeroussi \& Levy 2011) and emotional geographies of place, culture and de-industrialisation (Smith et al. 2009) with trenchant work coming from within working class studies (Linkon \& Russo 2002). Recent research has focused on the Left (Bonnett 2010) and on activism (Brown \& Pickerill 2009), as well as specifically on some post coal-mining settings (Perchard 2013). Notably, post-industrial locations have been recognised as sites of spectral affectivity 'in which the visible and the invisible, the material and the immaterial, intersect [where] ghosts, often barely present in the traces they left, stimulate the construction and transmission of stories which are not merely inarticulate but are suffused with affect' (Edensor 2005, p. 163). The idea that the past acts in the present through affective historical geographies of gender, class and race is, then, already well developed.

Nevertheless, Gordon's notion of a social haunting breaks distinctively new ground, particularly in

\footnotetext{
${ }^{8}$ Henceforward in this article, we are capitalising 'Care' to signal the informal feminine affective labour involved in a set of classed value practices based 'on reciprocity, care, shared understandings of injustice, and insecurity' to which Beverley Skeggs has drawn attention (Skeggs 2011, p. 509).
} 
foregrounding the relationship between haunting and the legacies of social violence - the 1984-85 UK Miners' Strike being, in our view, an exemplary case in point. Significantly, a social haunting, from Gordon's perspective, is also a generative phenomenon. In addition to registering levels of damage that may well be traumatic, it is also a 'socio-political-psychological state' (Gordon 2008, p. 57) that, most importantly, alerts us to positive futurities that reside immanently within a haunting and can be liberated by addressing how the past 'could have been and can be otherwise' (Gordon 2008, p. 57, our emphasis). To this end, a social haunting for Gordon requires that 'something different, different from before must be done' (Gordon 2008, p. xvi). Working with social haunting is of necessity, therefore, a politicised practice and, we would argue, a micropolitical practice at that (of which more later).

Why does Gordon's work speak so directly to the coalfield experience? Well, in a fairly obvious way really. Even though the Miners' Strike of 1984-85 is now thirty-five years past and UK deep-mining has now completely disappeared, the affective legacy of coal's singularly conflicted past endures as affective/imaginative intensities that continue to circulate through the absent presences of the industry, flowing now here and coalescing now there, in a complex material entanglement of historical, geographical, economic and psychosocial elements. The spontaneous 'Thatcher funerals' that celebrated the death of former UK Prime Minister, Margaret Thatcher, in 2013 are perhaps the most vivid example of the workings of these revenant energies (see Bright 2016).

\section{The coalfield gender question}

The question of gender relations in coalmining communities has been notoriously weighted with cultural, social and political significance. The outlawing of women's underground labour in 1842 was a major aspect in the production of working class 'femininity' and 'respectability', and the gendered division of labour in coalmining was a key factor in installing patriarchy as the unassailable authority within the emergent British labour movement as a whole, and within coalmining in particular (see Campbell 1986). Meanwhile, the 'paternal order' thus secured (see Beynon \& Austrin 1994) was reproduced through its privileged position within that very division of labour. Resurfacing regularly, the tension between the men's imposition of subservient domestic roles on women on the one hand, and their need for freely given gender solidarity at moments of industrial struggle on the other, remained unresolved within a 'geography of gender relations' defined primarily by an 'ideology of virility' (Massey 1994, p. 181). During the 1984-85 strike, however, the contestation that Campbell had represented as a battle with 'proletarian patriarchs' (Campbell 1986, p. 249) presented itself with renewed vigour with the growth of the women's support groups - the 'real radicals' for Campbell (p. 249) - transforming the strike from an industrial dispute to a communitywide social movement.

After the flowering of women's literature that occurred around that time, the topic of 'the women' has been infrequently reprised in the academic literature, even though coalfield women remain very strongly exercised by unfinished coalfield gender business (Bright 2018). For the duration of the strike, things changed as women's involvement developed out of their own community position into a 'politics of the doorstep' (Spence \& Stephenson 2007) that ranged out of and beyond the domestic space, journeying via a wider gender politics even into the conventionally masculine spaces of picket line action. The narrative of the strike as a heroic masculine 'struggle' has, however, remained conventionally gendered as the decades have gone by. Women's educational and social ambitions became once again difficult to express as the gender question retreated after the strike as a return to work re-engineered relationships back to 'normal' in the pit villages, and the domestic space was reprivatised within the doorstep once again. Thirty-five years later, the dark underside of patriarchy robust, and sometimes violent, male 'enforcement' - which had been already vocalised by key 
participants in one of our earlier projects (watch Discussion, Seaham. Part 2, 1.06 - 2.36, at https://spsheff.wixsite.com/songlines) was raised very sharply again in a contribution by a woman visitor to the first, On the Road Ghost Lab in Seaham, County Durham, and has emerged as the central theme of On the Road. We will examine women's affective contestations of that force in detail shortly but, first, a little more about the Ghost Labs.

\section{The Ghost Labs}

Fundamentally, a Ghost Lab is a participatory process space: a semi-improvised, horizontal, community/activist/arts workshop 'event space' (Massumi 2005) which aims to collectively reimagine 'what the ghosts might want from us' in Les Back's phrase (Back 2011). Its defining feature is a commitment to creating a safe place in which 'ghosts' are allowed to speak, come what may. Coproduced between a group of diverse academics, artists and activists, all of whom subscribe to a commitment to the Labs as an open, acceptant non-judgmental encounter governed by 'an ethic of caring for belonging' (Massumi 2015, p. 43), the Ghost Labs use a repertoire of playful arts devices to approach affective/imaginary materials that are hidden in plain sight in the life of our partner communities. The arts devices employed have commonly included what we've called 'ghost hunting'; co-operative and individual creative writing; comic strip production and - most frequently now - the 'community Tarot readings' mentioned at the outset.

In general terms of design, the Ghost Lab approach has been developed with an eye on the 'new material' turn in academic discourse, and within arts practice in particular. In specific terms, though, Kathleen Stewart's 'ficto-critical' ethnographic approach has been a signal inspiration. Stewart, has characterised her project in a way that resonates strongly with our experience in the Ghost Labs. It involves a

....slow, and sometimes sudden, accretion of ways of attending to the charged atmospheres of everyday life. How they accrue, endure, fade or snap. How they build as a refrain, literally scoring over the labour of living out whatever's happening (Stewart 2010b, p. 2).

Developing this point, she calls for an attunement to 'ordinary affects' that 'come into view as habit of shock, resonance or impact' (Stewart 2007, p. 1), that 'work not through 'meanings' per se, but rather in the way that they pick up density and texture as they move through bodies, dreams, dramas, and social worldings of all kinds' (Stewart 2007, p. 3). Ordinary affects, that is, are a kind of formally unintelligible and inherently ineffable excess that is 'worlded' through the process/labour of 'living out' the everyday - a notion that seems very close to Gordon's conception of social ghosts arising out of the 'blind field' of a haunting, and very close to what we have witnessed in the Ghost Lab, as we'll now detail.

\section{Washing lines, whinberries (the 'shit' card), and re-working 'waste ground'}

In this section, we attend specifically to those affective charges present in the densities and textures of ordinary affects that were 'worlded' in the rooms where our Ghost Lab activities took place. 9 Certainly, there were moments that 'glowed' (MacLure 2015) - sometimes darkly - and stayed with us long after we left. We came to realise fairly quickly that the ghosts that made themselves known across the sessions murmured insistently (if obliquely) of the impacts of social and gender violence, both symbolic and actual, in women's lives.

\footnotetext{
${ }^{9}$ To ensure confidentiality we will not reveal locations and will move frequently between different moments in different Ghost Labs.
} 
In each session, we started by showing the assembled group short films we had made independently with communities in either the Welsh or northern coalfield sites. One of the films, called Light Moves had been made with young people in south Wales. At the time it was made, the young people involved had been keen to speak back to a 'documentary', Skint,${ }^{10}$ screened on television in 2015 during the period when Ivinson and her colleagues were working with the community there. In the opening scene of Light Moves, the camera scans the landscape around a well-known housing estate in an ex-mining valley town in south Wales, panning across back gardens and clotheslines strung with multi-coloured garments. The deep, gentle voice of the young narrator speaks of her strong sense of belonging to the place and the community.

This film was shown in each of the Ghost Labs discussed in this article. In the south Wales Lab that we are mainly focusing on here, people sitting at the tables around the room began to respond spontaneously and volubly immediately after Light Moves ended. Although the film had been created to primarily to emphasise the 'good' side of the estate, contra Skint, comments indicated that it was its 'bad' reputation that remained the salient feature. One woman, who we will call Fran - who clearly recognised the housing estate - told the assembled group how her granddad, a coalman, used to deliver coal to the estate and recounted how he disliked delivering there because the coal would get stolen off the back of that cart, saying: 'If it can move, it will be gone'. The 'estate [had] such a bad reputation, even in the past', Fran insisted.

Having worked on the estate, Ivinson had heard this refrain repeated many times. Stories about the 'bad' reputation of the estate circulated around the area as 'well told tales', and had become part of the contemporary mythology of the place. Bright was reminded strongly of how young people in English mining communities will lay claim to their local habitation as a 'shit hole' or 'the worst place in the world' but vociferously refuse such a descriptor if it is used by an outsider. Such tales have a double function: they both signal the real levels of poverty and precarity that have endured across time in such places and, in boldly re-claiming and owning such a marginal space of negation, also refuse victimhood (see Bright 2011).

Interestingly, one of the other On the Road Ghost Labs involved a return to the actual estate. There, we showed the films and, in the conversation that followed, people told us that the situation had, in fact, got worse in the area and blamed it on 'austerity' economic policies. We had invited artists to the Ghost Labs to sit among us to listen to comments and attune to the atmosphere. One of the artists, Valerie Walkerdine, presented a list of things that she found to be troubling people (reproduced, here, from her field notes):

We had jobs - Now no options - You could change jobs then - in and out now - zero hours contracts.

House prices have risen dramatically.

Thatcher moved people off employment and onto the sick.

Mental health - dire straits. Government have tied our hands. People losing homes.

Food banks under enormous pressure. Kids starving now, worse than the miners' strike.

Feeling the 'hopelessness and impotence', Valerie (as the artist) wrote in her field notes:

\footnotetext{
${ }^{10}$ Skint is a British documentary series broadcast in three series between May 2013 to 27 April 2015 on Channel 4, a UK TV Channel. The third series was filmed in south Wales.
} 
It was nightmarish, Kafka-esque, hopeless. I wanted to make a work that was a list of all those increases and 'no money' 'no money' 'no money'. I had the feeling of a desolated WW1 landscape.

Back in the Lab with Fran, we listened to her referring again to documentaries like Skint, noting how people like her are positioned by those who produce such programmes as a kind of exotic, but deeply inferior, 'other' who is momentarily interesting only in so far as s/he might provide an opportunity for a fascinated sneer on the part of the supposedly more 'sophisticated' viewer. At this point, the 'washing lines' again made an appearance.

They think we are backward, old fashioned. They come up from London and Cardiff, these townies and take pictures. They took pictures of me smoking a fag out back, by the washing line. When they did that, all my aunt's smalls were put on public display! We are old fashioned in terms of values, but we are not backward. We don't want to be like them (GI \& GB field notes).

In 'Steeltown', their seminal study of affective impacts of de-industrialisation in Wales, Walkerdine and Jiminez (2012) had noted how women used the low fences between their houses of their estate as a hub of relationality and vernacular knowledge-exchange in a gendered creative social practice which bound them mutually and supportively together. In Fran's parallel example, 'smoking a fag out back by the washing lines' went entirely misrecognised, being seen as an illustration of provincial parochialism by the metropolitan 'London' film crew.

In the Ghost Lab, the conversation circulated and this particular affective charge related to negative valuations of working-class people (and working-class women, in particular) intensified as others expressed how ex-coalmining communities continue to be marked as 'different' Yet the session always proceeded with a robust good-humour such that we, as literal outsiders ${ }^{11}$ to this particular group, felt embraced with warmth, even as phrases echoed Fran's expressed fury at being judged as inferior by 'outsiders'. At one point, one of the women - who we will call Jan - referred to a piece of dialogue in Light Moves where the speaker refers to a childhood experience of collecting whinberries; a berry most notable for being indistinguishable from 'sheep poo'. This promptly led us into a raucous discussion of whether we needed a 'Shit' card in the Tarot pack and, in a moment of pure comedic improvisation, the same women - whose life had already been quietly indicated as a very difficult one ('full of shit', as she said) - revealed that she had sat and quietly drawn us our additional card during the discussion: a sprig of whinberries and the word 'shit'. The same refusal of victimhood already registered by Fran was, we would suggest, being reprised in this re-claiming of a (now transvalued) negative term. 'Shit', one might say, was deeply ingrained in the women's lives, but owning its stain together allowed them, somehow, to transcend it.

A little later, this same recognition of value being immanent in conditions of devaluation made itself present again in a powerful and generative way. After lunch, the Tarot cards were dealt once more and, amid much mirth and banter, the women chose their three cards; past, present and future. By this point in the afternoon, the men who had been with us before lunch had left. We were now a group of nine women, two younger men (students) and we three visitors, and the atmosphere had changed, having become much more intimate. There was a heightened sense of anticipation as Lizzie turned over her cards. The first card was 'Care'. A hush descended and we felt an unarticulated communal knowing shift rapidly around the room, gripping each woman, holding her still in her

\footnotetext{
${ }^{11}$ Our distance as outsiders from this group varied in complex and significant ways that related to a shifting nexus of gender, work background and individual biography, a point that merits a longer discussion than we have the space for here.
} 
place. The affective charge quite stunned us, making us suddenly aware of the gravity of the knowing. After a long pause and many facial grimaces, Lizzie announced:

'I will not be talking about the past'

All the others knew what Lizzie was referring to and, for a few very significant moments, the exquisite affective attention of the group held Lizzie, enabling her to occupy multiple affective states one after another and simultaneously, letting the complexity of things simply 'be', without anyone attempting to close matters down and make them 'safe'. An 'ethics of caring for belonging', a micropolitics of affect (Massumi 2015), was being performed in a thorough-going way. The group had a remarkable facility in looking after Lizzie as her undisclosed trouble ${ }^{12}$ surfaced and her distress was held in silent care by the other women. Indeed, Care - warranted by a vernacular knowing from the women's collective past - seemed to allow affective dispersal to happen while at the same time enabling elements to be remembered, brought into common, held there, and acknowledged in the space that was now protecting Lizzie. We three visitors were touched, too, by Care's presence and felt its gravity. Clearly, these women had frequently found themselves in situations where painful memories had been worlded and lived through, and they knew what to do to look after each other.

Throughout the Tarot card readings, as women turned over the 'past', 'present' and 'future' pictogram cards, the communicative web pulsed, vibrated and tangled. Words spoken hinted at things indirectly. Every so often, gestures intensified and came to a crescendo in laughter. At one moment, reassuring, supportive comments were directed by all the women at one of the younger mums, called Kim:

'The boys are a credit to you!'

'Everything I have ever heard from teachers is how well you have done with the boys.'

We now experienced Care being performed once more, very explicitly and consciously as another version of the 'trouble' was invoked, and the women turned their lavish attention to Kim - a stratagem that community worker who had given us access to the group later as a 'love-bomb'.

\section{On Waste Ground}

After this spontaneous shift to supporting Kim, Lizzie turned over her second and third - 'present' and 'future' - cards. She seemed puzzled. Her cards were 'Whisper' and 'Waste Ground', with 'Waste Ground' being the future card. Immediately, there was a slump in energy that impacted across the whole group. After a while, one of us decided to make an intervention, saying:

'You can build on waste ground'.

This seemed to immediately open another line of flight and the conversation flowed again. The women talked about buildings and who lived in which houses. The tightly packed rows of terrace houses where were the ex-coal mining families lived. The managers had once lived in the bigger house on the hill-top looking down onto the terraces below. They spoke of gendered hierarchies within the community and soon the talk turned to the present. They told us of the religious factions

\footnotetext{
${ }^{12}$ We are minded here of how Donna Haraway (2016) talks of the 'trouble' as that which simmers below what is explicitly articulated in a group, and yet which indicates an unresolved, often inter-generational, problem that will not go away, and which keeps appearing as a ghost.
} 
and how, even to this day, the male elders will not take part in Halloween festival or help in the community centre. We glimpsed deeper contours of the trouble, suppressed emotions, denial of the sensual body and strong masculine - feminine divides. We were told that when the children made a mural to commemorate the end of WW1, the elders refused to let the young ones place the mural on the War Memorial. We could feel a pattern found in other communities, of the elders, especially men, holding on to familiar practices of the past.

Listening to the stories, we felt two features emerging. First, that it was the women who were the rebuilders, because only they could acknowledge that the 'waste ground' of the past - of both the physical places and of the collective heart - was actually exhausted. Secondly, that we were edging ever closer to the un-named trouble, but it did not reveal itself until right after the Ghost Lab ended. Later, when we were milling around outside the civic centre, waiting for a taxi back to the railway station (which, incidentally, never came), we huddled outside the main entrance of the community centre in small groups. Kim, the love-bombed young woman, confided in one of us, speaking of her extensive personal experiences of traumatic domestic and sexual violence in a situation that put the care of her children in peril.

Once this issue was spoken, a web of connections were suddenly apparent. The spectre shimmering darkly in the atmospherics of the Welsh Lab was the very same figure of emotional, physical, and sometimes sexual, abuse of girls and women that had been clearly named in one of the English Ghost Labs. There, one woman, Sara, had called out angrily: 'It was not all good! The men were hard, the labour was hard, and they were hard with us!'.

\section{Storying in common: narrative fabulation as a micropolitical process?}

What is it that we witnessed here, and how might we explain it theoretically and practically? As part of our separate work, Bright has written extensively on the affective legacy of the 1984-85 UK miners' strike as it continues to have an impact on coalfield social life in general but, in particular, on how responses to schooling and education are influenced by classed gender aspects of the conflicted history of coalfield labour relations (see Bright 2012a, 2012b, 2016). Ivinson, in complementary contrast has focused on how such impacts continue to play out in terms of performative gender practices among marginalised young people (Ivinson 2012; Ivinson \& Renold 2013a, 2013b).

For the most part, Bright has used Gordon's work - with its origins in what Gordon has been happy to call a 'magical Marxism' that pays strong attention to dissident Marxisms in Ernst Bloch's, Walter Benjamin's and Raymond Williams' work - to begin thinking this through. Ivinson, on the other hand, has deployed an approach bringing together feminist post-structuralism and new materialism. Interestingly, the space between these sometimes counter-posed orientations has actually been richly productive as we are both very persuaded of the value of affect theory and approaches to group work in radical psychology (particularly in the oeuvre of Guattarri). It has allowed us to think in novel ways about how a simple 'divination' game can open up the reservoirs of 'unlicensed' affective energy that mark a social haunting. Below, we offer some of our preliminary thoughts as to the dynamics of this process.

In the first place, the design of the Tarot game was a purposeful one. The intended simplicity and horizontality of the 'reading' has clearly been significant in practice. It allows for open, divergent responses to participant's own lives, and the only knowledge required for participation is the subject's lived experience (in which the subject is, of course, the only 'expert'). We use a simple three-card reading from a pack of cards, each of which carries a word or an image that has been 
generated with our communities. So, while the card 'topics' can seem random, they have in fact emerged from vernacular imaginations that our Ghost Lab groups have broadly shared. ${ }^{13}$ Secondly, the levelled, transversal, ethos of the Labs - that 'ethic of caring for belonging' referred to earlier enacts a radically different process of group subjectivation, as we'll see. After reassurances that the person undergoing the reading is in complete control of her/his responses and can terminate the reading whenever s/he wishes, three cards are dealt: one a 'past' card, one 'present' and one 'future'. Immediately, temporal relationality (and its mystery) is opened up as a fluid space for a set of interactions between the 'reader' (or readers - often, in reality, the whole group will feed into the reading) and the person whose cards are 'being read'. Throughout, the 'reading' is storied in a way that is light-heartedly performative and intentionally 'improvisative' (see McMullen 2016).

'Storying', or narrative fabulation, certainly appeared to be a central feature of what was happening with the Community Tarot cards in the Ghost Labs that were part of the original 2015-18 AHRC projects. We were clearly dealing with a poetics there - a poetics where the existential could be seen to meet the aesthetic and the affective at a micro-perceptual level (Massumi 2015), and this microperceptual aspect has been particularly important for us in thinking about how we might conceive of an emergent politics of the Ghost Lab setting, a matter that is of particular interest to us both. As we saw earlier, Gordon had originally emphasised how a social haunting always carries a politicised imperative (a 'something that needs to be done') and that means that a social haunting always exceeds any simply traumatic content that it routinely carries.

Now, the storying with which we had become familiar was just as present in the On the Road Ghost Labs, as it was in all the specifically coalfield Ghost Labs, but the presence of trauma was even more emphatic. Might one not plausibly argue, then, that looking for a politics in such pained and injured settings is wrong-headed, and that the primary role of the Ghost Labs in heavily traumatic contexts should more properly be developed as a therapeutic one? Conventional wisdom in community 'wellbeing' would certainly warrant the rolling-out of such processes if the therapeutic and palliative aspects could be neatly isolated and codified and, in truth, we have felt discursive pressure from the UK research 'impact' agenda to conform to that expectation. However, as radical researchers, we contest that agenda, arguing that an accommodation to dominant policy formulations and practice protocols would likely mean a pacification of the flows of life that moved, however painfully, through our Ghost Labs. On the contrary, the kind of affective/imaginative production in common; the collective storying and 'living through'; of coalfield women's experience that occurred in the $O n$ the Road Labs is transformative in its own right and constitutes, we believe, a micropolitical process that challenges the pharmaceutical interventions that have become commonplace across the coalfields.

So how might we understand a micropolitics of narrative fabulation? Interestingly, anthropologist Peter Collins has recently considered the challenge that the notion of haunting poses for anthropology, and emphasized that '[g]hostly presence reaches beyond the allegorical and metaphorical' and, further, that the 'relationship between imagination and haunting is complex [and is] an imaginative process... itself inherently social and generative of relationships... that has been largely overlooked'. Hauntings, he suggests, 'can only be understood... in relation to narrative' (Collins 2018, p. 99, our emphasis) and, what is more, 'the narrative gaps, spaces, lacunae' that are characteristic of them 'are completed or repaired, most often by the prompting of ghosts' (Collins 2018, p. 111), a process that is recognisable in the Ghost Lab exchanges that we witnessed in the women's accounts given above.

\footnotetext{
${ }^{13}$ The Community Tarot pack does, though, require adaptation and translation for work with diverse groups.
} 
In so far as the Ghost Lab can reasonably be seen as a 'small, moveable environment[s] of potential' (Massumi's definition of the micropolitical, in Massumi 2015), then Guattari's notion of 'resingularisation' of subjectivity (Guattari 2015, p. 97) as the micropolitical core of group practice is significant for the phenomena that we have observed. Massumi describes the micropolitical as a return to the 'generative moment of experience at the dawning of an event, [a] brewing, a world stirring' (Massumi 2015, p. 52). Each such moment, experienced micro-perceptually, opens the possibility of 'reconnecting processually with what is germinal in... living' (Massumi 2015, p. 79) and raises the prospect of 'living more intensely, more fully, with augmented powers of existence' (Massumi 2015, p. 79); 'micropolitics, affective politics, seeks the degrees of openness of any situation, in hopes of priming an alter accomplishment' (Massumi 2015, p. 52) while 'chipping away at the macro problems' (Massumi 2015, p. 79).

More widely, in Three Ecologies, (Guattari 1989) Guattari had proposed a 'mental ecology' as a necessary feature of our freeing ourselves from the catastrophe of what he calls Integrated World Capitalism. Key to that mental ecology, is the re-singularisation of subjectivity that emerges from transversal therapeutic group-work practice. For Guattari, singularity is not individuality, although it is about being singular. In Gauttarian group-work, re-singularisation is the hinge of the move from the paralysis of the subjected group to the autonomous energy of the micropolitical subject group. It is an ongoing aesthetico-existential-affective process that is inherently anti-individualistic, and thus reaches beyond any liberal political model of liberation, hence its political radicality.

\section{Re-singularisation in common: the Ghost Labs' politics of ordinary affects}

It strikes us that the Ghost Labs' distinguishing feature is precisely their capacity to amplify 'ordinary affects' in a way that facilitates the repair and completion that Collins identifies, but through micropolitical re-singularisation, as conceived by Guattari. Kathleen Stewart's language - of flows and of pause and acceleration; of accruals and fractures; of embodied dreaming; of densities, textures and, notably, of the refrain of forces and intensities - is the Ghost Labs' natural register to be sure, just as the Lab's laboratory space is the natural locus of these forces' collective 'worlding'. And ghosts certainly are (in Collins' sense) made material there by being transformed 'from the apparitional through the concerted efforts of participants who are familiar with their haunting presence' (Collins, p. 111). Guattari's description of how a group moves from being a 'subjected' group to becoming a 'subject' group moves us significantly further on, though. It allows us to see how, in the detail life of an unfolding Ghost Lab, affects and feelings that are initially held privately become available for holding in common in a process that is essentially a re-singularising one for all the individuals involved - and that, we would argue, is the substance the Ghost Labs' classed and gendered micropolitics, and we find a hopefulness in that.

Jean Spence and Carol Stephenson reminded us a decade ago how values associated with 'mining community' remain relevant 'for a self-conscious, politicised reshaping of local relationships in postindustrial conditions' (Spence \& Stephenson 2007, p. 309) - but only as long as 'the apparently gender-neutral ideal of mining 'community' is interrogated' (Spence \& Stephenson 2009, p. 68). In ex-mining localities, co-operation - the fundamental bond of 'solidarity' - has, as they noted and as we have witnessed, 'shifted from the industrial front to what traditionally has been the female sphere associated with friendship, kin and neighbourhood' (Spence \& Stephenson 2007, p. 325) and it is an understanding of the 'nature of agency exercised by women activists in these circumstances' that

suggests the possibility of building new and more extensive forms of political organization which interconnect the separate spheres of work and home, public and private, male and female (Spence \& Stephenson 2007, p. 325). 
This thread needs to be picked up again, as Valerie Walkerdine has recognized. Drawing on the psychoanalyst Bracha Ettinger, Walkerdine articulates a feminist reclamation of the notion of a community as a matrixial space ${ }^{14}$ in which the affective mantle and burden of pain and depression borne by the women in de-industrialised communities, might be taken away from them and, instead, shared by men and women together in 'a shifting of the distance between femininity and masculinity' (Walkerdine \& Jiminez 2012, p. 176, our emphasis). Further, Walkerdine's more recent account of how affective histories of communities make themselves present through small, anecdotal details in conversations and interviews that, taken together, constitute a space of community selfdetermination (Walkerdine 2016), effectively proposes a research approach not unlike that of the Ghost Labs. While this matrixial re-orientation shifts the focus from the wider haunting of the coalfields on to the gendered haunting within a haunting of the coalfield women, it also has to be a classed shift. In an important 2011 article, Beverley Skeggs argued for a 're-legitimation of [working-class women's] classed value practices' based 'on reciprocity, care, shared understandings of injustice, and insecurity' (Skeggs 2011, p. 509) as an autonomous model of social transformation. In producing such value practices, it is necessary for girls and women to 'establish which practices [are] just and with value'. Such classed gender work routinely enters 'different, nearly always local, circuits of value and generates alternative values about 'what/who matters', 'what/who counts' and 'what is just'” (Skeggs 2011, pp. 505-506).

\section{Conclusion}

In the On the Road Ghost Labs we saw the 'classed value practices' of working-class women's power to Care unfold as a micropolitical aspect of their being together. Perhaps that is how the ghost of the women of the mining areas might eventually be named more publicly as a challenge to the continuing dominance of heroic masculinity and virile action in the rhetoric of coal and its conflicts, particularly the 1984-85 strike. We also saw the productive capacity of the matrixial enactment of a DIY solidarity which was anchored in the calm, powerful mutuality of groups of women. Together, the women seemed rooted in their collective being in a way that could live through the 'hard stuff' that could not be spoken (being dealt the 'shit card') and, at the same time, allow them to move beyond their own personal pain to a holding of pain in common that enabled them by virtue of that, to become a subject group of re-singularised individuals in Guattari's terms, living more intensely, more fully, with augmented powers of existence, as Massumi put it. As these changes happened, no one was overwhelmed, no one ran out of any of the sessions. Just occasionally someone left the room quietly for a while, came back, settled back down and slotted back with ease into the rhythms of the non-verbal dance of collective meaning-making and value creation. Everybody knew, nevertheless, that something of moment was occurring, invoked in the main by the playful conjuring of a handful of cards.

In all cases, the steadiness of the women facilitators who had nurtured their groups for a long time before our appearance, was a very telling factor. We could see that clearly. Equally, in each group there were key figures and more peripheral individuals. Nevertheless, the generative affective work that we observed was being successfully shared inter-generationally and with a range of others, thus encompassing a dialogic reach that exceeds that aspired to in most formal educational and support contexts. In those different community rooms, on the different days of our project, these groups of coalfield women enacted their autonomous micropolitics of 'Care in common'. In doing so, the rich productivity of women's informal value practices in the psycho-social life of the now deindustrialised coalfields was made abundantly clear, speaking back in a definitive and richly hopeful

\footnotetext{
${ }^{14}$ i.e. as appertaining to the womb, or specifically in Ettinger's work, the uterus
} 
way not only to the marginalisation of women's role in the 1984-85 strike, but also to the idea that the women's specific experience of struggle is no longer relevant at the final end of 'King Coal'.

\section{Author Bios}

Geoff Bright is a former Research Fellow and currently a Visiting Scholar at ESRI. A former steel worker and rail worker, he has a work background in trade union, adult and further education and an academic background in philosophy. His $\mathrm{PhD}$ study was an ethnography of the intergenerational intersection of class, place and gender as it impacts on education in deindustrialized coalmining communities, and his current work grows out of a lifelong relationship to mining communities and ideas of independent working class education. He is now leading his fourth AHRC Connected Communities funded project in that area, which uses arts-based methods and the idea of a 'social haunting' to co-produce possible futures for such communities. He is also currently involved in the EU funded Partispace project which is looking into 'styles and forms of participation' among under 30s, and is a network convener for the ethnography network at the European Education Research Association (EERA). His 2016 article in Ethnography and Education: 'The lady is not returning!: Educational precarity and a social haunting in the UK coalfields' won the WCSA international prize for best academic article.

Gabrielle Ivinson currently works at the Education and Social Research Institute, Manchester Metropolitan University. Gabrielle does research in Social Psychology, Pragmatics and Discourse Analysis. Their current project is 'Creative Margins: Building capacity in arts-based pedagogies through dialogues between arts organisations, youth workers and community educators.'

\section{Bibliography}

Back, L. 2011, Haunted Futures. A response to Avery Gordon. In Borderlands. 10: 2. No page.

Beynon, H. \& Austrin, T. 1994, Masters and Servants: Class and patronage in the making of a labour organisation. London: Rivers Oram Press.

Bonnett, A. 2010, Left in the Past: Radicalism and the Politics of Nostalgia, New York, Continuum.

Bright, N. G. 2020, 'Feeling, Re-imagined in common: Working with Social Haunting in the English coalfields'. In Routledge International Handbook of Working Class Studies (eds.) Tim Strangleman, Michele Fazio, Christie Launius. London and New York: Routledge.

Bright, N. G. 2018, “A chance to talk like this': Gender, education, and social haunting in a UK Coalfield'. In Smyth, J \& Simmons, R (eds.) Education and Social Class. London: Palgrave.

Bright, N. G. 2016, "The Lady is not returning!': Educational precarity and a social haunting in the UK coalfields'. In Ethnography and Education, vol.11, no.2, pp. 142-157.

Bright, N.G. 2012a, 'It's not a factory!' Performative educational provision for marginalised and excluded youth in a former UK coal-mining community. In Jeffrey, B. \& Troman, G. 2012 Performativity across UK education: ethnographic cases of its effects, agency and reconstructions, Painswick: E\&E Publishing. 217-240.

Bright, N.G. 2012b, 'Sticking together!' Policy activism from within a former UK coal-mining community. In Journal of Education Administration and History, vol. 44, no.3, pp. 221-236.

Bright, N.G. 2011, 'Non-Servile Virtuosi' in insubordinate spaces: School disaffection, refusal and resistance in a former English coalfield'. In European Education Research Journal, vol.10, no.4, pp. 502-515.

Brown, G. \& Pickerill, J. 2009, 'Space for Emotion in the Spaces of Activism', Emotion, Space and Society, no.2, pp. 24-35.

Campbell, B. 1986, 'Proletarian patriarchs and the real radicals'. In Seddon, V. The Cutting Edge: women and the pit strike, London, Lawrence and Wishart. 
Edensor, T. 2005, Industrial Ruins: space, aesthetics and materiality. Oxford: Berg.

Facer, K. \& Enright, B. 2016, Creating Living Knowledge, Bristol, University of Bristol and AHRC Connected Communities Programme.

Fentress, J. \& Wickham, C. 1992, Social Memory, Oxford, Blackwell.

Gauttari, F. 1989, The Three Ecologies. London: Contimuum.

Guattari, F. 2015, Psychoanalysis and transversality: Texts and interviews 1944-1971. South Pasedena, CA: Semiotext(e).

Haraway, D. 2016, Staying with the Trouble: Making Kin in the Chthulucene. Durham: Duke University Press.

Ivinson, G. 2012, 'Boys, skills and class: Educational failure or community survival? Insights from Vygotsky and Bernstein'. In H. Daniels (ed.), Vygotsky and Sociology. London and New York: Routledge.

Ivinson, G. 2014, 'Skills in Motion: boys' motorbiking activities as transitions into working class masculinity' Sport, Education and Society, vol.19, no.5, pp. 605-620.

Ivinson, G. \& Renold, E. 2013a, 'Subjectivity, affect and place: Thinking with Deleuze and Guattari's Body without Organs to explore a young girl's becomings in a post-industrial locale'. Subjectivity, vol. 6, no.4, pp. 369-390.

Ivinson, G. \& Renold, E. 2013b, 'Valley Girls: Re-theorising bodies and agency in a semi-rural postindustrial locale', Gender and Education, vol. 25, no.6, pp. 704-721.

Knudsen, B \& Stage, C. (eds.) 2016, Affective Methodologies: Developing Cultural Research Strategies for the Study of Affect, New York, Springer.

Linkon, S. \& Russo, J. 2002, Steeltown USA: Work and Memory in Youngstown. Kansas: University Press of Kansas.

MacLure, M. 2015, 'The 'new materialisms': a thorn in the flesh of critical qualitative inquiry?' In G. Cannella, M. Perez, \& P. Pasque, (eds.) Critical qualitative inquiry: foundations and futures. Walnut Creek: Left Coast Press.

Massey, D. 1994, Space, place and gender. Cambridge: Polity Press.

Massumi, B. 2015, The Politics of affect. Cambridge: Polity.

McMullen, T. 2016, 'The improvisative'. In Lewis, G. \& Piekut, B. (eds.) The Oxford handbook of critical improvisation studies, Volume 1, Oxford, Oxford University Press.

Olick, J., Vinitsky-Seroussi, V. \& Levy D. (eds.) 2011, The Collective Memory Reader, Oxford, OUP.

Perchard, A. 2013, “'Broken Men' and 'Thatcher's Children': Memory and Legacy in Scotland's Coalfields', International Labor and Working-Class History, no.84. pp.78-98

Seigworth, G. \& Gregg, M. (eds.) 2010, The Affect Theory Reader. Durham NC and London: Duke University Press.

Skeggs, B. 2011, 'Imagining personhood differently: person value and autonomist working-class value practices'. In Sociological Review, vol. 59, no.3, pp. 496-513.

Smith, M, Davidson, D, Cameron, L, \& Bondi, L. (eds.) 2009, Emotion, Place and Culture, London and New York, Routledge.

Spence, J. \& Stephenson, C. 2007, 'The politics of the doorstep'. In Community, Work \& Family. Vol.10, no.3, pp. 309-32.

Spence, J. \& Stephenson, C. 2009, 'Side by side with our men? Women's activism, community and gender in the 1984-5 British Miners' strike'. In International labour and working-class history, vol.75, no. 1, pp. 68-84.

Stewart, K. 2007, Ordinary affects. Durham NC and London: Duke University Press.

Stewart, K. 2010a, 'Worlding refrains'. In Seigworth, Gregory. J. \& Gregg, M. (eds.) The Affect Theory Reader. Durham NC and London: Duke University Press. 339-353.

Stewart, K. 2010b, 'Atmospheric attunements', Rubric, no.1, pp. 1-14. 
Walkerdine, V. \& Jimenez, L. 2012, Gender, work and community after de-industrialisation: A psychosocial approach to affect. Basingstoke: Palgrave Macmillan.

Walkerdine, V. 2016, 'Affective History, Working Class Communities and Self Determination', Sociological Review, vol. 64, no.4, pp. 699-714.

Williams, R. 1977, Marxism and Literature. Oxford: Oxford University Press. 